\title{
PENGARUH IKLIM KELAS TERHADAP MOTIVASI BELAJAR PESERTA DIDIK KELAS VIII PADA MATA PELAJARAN PENDIDIKAN KEWARGANEGARAAN
}

\author{
Ichwani Siti Utami dan Ratna Atiah \\ Fakultas Keguruan dan Ilmu Pendidikan, Universitas Pamulang \\ amiutami10@gmail.com
}

\begin{abstract}
Abstrak
Penelitian ini bertujuan untuk mengetahui: (1) gambaran umum tentang iklim kelas. (2) gambaran umum tentang motivasi belajar, (3) pengaruh iklim kelas terhadap motivasi belajar. Metode penelitian yang dipergunakan adalah deskripsi kuantitatif. Unit analisis adalah peserta didik kelas VIII sekolah menengah pertama (SMP) Era Pembangunan 3 Jakarta pada mata pelajaran Pendidikan Kewarganegaraan. Teknik pengambilan data dengan cara menyebar angket. Populasi penelitian ini adalah peserta didik kelas VIII SMP Era Pembangunan 3 Jakarta berjumlah 194 peserta didik. Teknik pengolahan data menggunakan uji validitas, uji reliabilitas, uji normalitas, dan regresi linier sederhana. Hasil penelitian menunjukan bahwa di dalam kelas yang kondusif terdapat semangat belajar peserta didik yang tinggi, hal ini nampak pada saat guru memberikan pelajaran dengan baik sehingga terciptanya suasana kelas yang menyenangkan dan peserta didik merasa diperhatikan. Dari penelitian ini disimpulkan bahwa iklim kelas berpengaruh terhadap motivasi belajar siswa senilai 0,2877 dan korelasi antara variabel $(X)$ dan variabel $(Y)$ sebesar 0,645 itu berarti korelasi tersebut sangat kuat, artinya $\mathrm{H} 1$ dapat diterima dan $\mathrm{HO}$ ditolak. Hal ini berarti terdapat pengaruh positif antara iklim kelas terhadap motivasi belajar peserta didik pada mata pelajaran Pendidikan Kewarganegaraan kelas VIII SMP Era Pembangunan 3 Jakarta, hal ini dibuktikan dengan $F$ hitung sebesar 0,2877 yang berarti pengaruh iklim kelas sebesar 28,77\% selebihnya dipengaruhi oleh faktor lain. Diantaranya faktor intrinsik berupa hasrat, keinginan berhasil, dorongan kebutuhan belajar, harapan akan cita-cita dan faktor ekstrinsik berupa lingkungan kelas.
\end{abstract}

Kata kunci: Iklim kelas, Motivasi belajar.

\footnotetext{
Jurnal Pendidikan Kewarganegaraan

Journal of Civics and Education Studies

The journal is published by Department of Civic Education

Faculty of Teacher Training and Education

Universitas Pamulang - Indonesia
}

Copyright $\odot 2017 \mid$ ISSN: 2302-0865 


\section{PENDAHULUAN}

Belajar sangat penting dalam kehidupan setiap individu terutama sebagai peserta didik. Namun belajar tidak selalu menyenangkan bagi beberapa peserta didik. Pembelajaran suatu proses yang rumit karena tidak sekedar menyerap informasi dari guru, tetapi juga melibatkan berbagai kegiatan dan tindakan yang harus dilakukan untuk mencapai hasil belajar yang baik. Guru bertanggung jawab untuk mengatur, mengarahkan, dan menciptakan suasana yang mendorong siswa untuk melaksanakan kegiatan-kegitan di kelas. Pendidikan menurut undang-undang No 20 tahun 2003 pasal 1 tentang sistem pendidikan nasional adalah usaha sadar dan terencana untuk mewujudkan suasana belajar dan proses pembelajaran agar peserta didik secara aktif mengembangkan potensi dirinya untuk memiliki kekuatan spiritual, keagamaan, pengendalian diri, kecerdasan akhlak mulia serta keterampilan yang diperlukan dirinya, masyarakat bangsa dan negara.

Menurut Namin, guru merupakan ujung tombak pendidikan. Tetapi, saat ini guru minim mendapatkan pelatihan yang berkualitas. Ketiga, kata Namin, budaya literasi di kalangan guru masih sangat lemah. Sedangkan permasalahan keempat buku teks pelajaran yang digunakan masih rendah. Menanggapi dualisme kurikulum yang saat ini diterapkan di seluruh sekolah yang ada di negara ini yakni Kurikulum 2013, Kurikulum 2006 (KTSP), Mendikbud tidak banyak mempermasalahkannya. hanya saja, ke depannya penggemblengan kualitas guru sebagai sosok yang digugu dan ditiru itu dipastikan yang akan diutamakan. "Karenanya, kualitas pendidikan tidak ditentukan kurikulum berganti atau tidak, namun kualitas pendidikan itu sangat ditentukan oleh kualitas gurunya," tandas Muhadjir (Beritasatu.com, 2017). Menurut Davis, Winsler, dan Middleton, dalam kutipan Hadinata Priatna bahwa perhatian dari pengajar merupakan salah satu komponen yang membuat suatu iklim kelas menjadi positif (Beritasatu.com, 2017). Motivasi belajar merupakan syarat mutlak untuk belajar, memegang peranan penting dalam memberikan gairah atau semangat dalam belajar. Tujuan dari belajar adalah mendapat hasil yang baik. Banyak peserta didik yang mengalami masalah dalam belajar akibatnya hasil belajar yang dicapai rendah. Untuk mengatasi hal tersebut perlu ditelusuri faktor yang mempengaruhi hasil belajar terutama motivasi belajar peserta didik. Menurut Wlodkowski dan Jaynes dalam kutipan Hadinata Priatna menyebutkan bahwa iklim kelas termasuk ke dalam faktor sekolah yang merupakan salah satu faktor yang memengaruhi motivasi belajar.

Permasalahan yang peneliti temukan pada saat pelaksanaan penyebaran kuesioner di kelas VIII pada mata pelajaran pendidikan kewarganegaraan menunjukkan rendahnya motivasi belajar peserta didik dalam pembelajaran yang dapat terlihat ada sebagian peserta didik yang selalu mengobrol dengan teman sebelahnya, peserta didik selalu keluar masuk kelas saat guru menjelaskan 
dengan alasan izin ke toilet dan tidak ada peserta didik yang mengajukan pertanyaan bahkan siswa saat belajar lebih suka gaduh sehingga kondisi pembelajaran dikelas kurang kondusif. Motivasi belajar peserta didik tersebut akan mempengaruhi bagaimana proses pembelajaran di dalam kelas. Sebuah proses pembelajaran yang didukung dengan motivasi belajar akan berjalan lebih efektif. Dengan adanya suasana lingkungan belajar yang baik peserta didik akan memiliki kesiapan dan persiapan untuk belajar. Selain itu, dukungan iklim yang kondusif akan memberikan dampak yang positif bagi peserta didik dan tentunya berpengaruh juga terhadap motivasi belajar peserta didik.

Berdasarkan latar belakang diatas, maka dapat diidentifikasikan masalah sebagai berikut; 1) Rendahnya kualitas guru di sekolah; 2) Jumlah buku pelajaran yang digunakan di sekolah masih kurang; 3) Iklim kelas kurang kondusif terlihat peserta didik tidak nyaman di kelas; 4) Pemetaan kelas kurang efisien terlihat ruang kelas SMP berada diantara ruang kelas SMK; 5) Kurangnya semangat belajar pada peserta didik terlihat tidak ada peserta didik yang mengajukan pertanyaan saat proses pembelajaran di kelas; dan 6) Rendahnya motivasi belajar peserta didik terlihat saat pembelajaran sebagian peserta didik keluar masuk kelas dengan alasan izin ke toilet.

Berdasarkan latar belakang masalah dan identifikasi masalah maka penelitian ini dibatasi pada pengaruh iklim kelas terhadap motivasi belajar peserta didik kelas VIII pada mata pelajaran pendidikan kewarganegaraan. Adapun yang dimaksud dengan iklim kelas adalah kondisi tempat dimana peserta didik dan guru berinteraksi satu sama lain dengan menggunakan beberapa sumber informasi dalam usaha pencarian ilmu dalam aktifitas belajar. Sedangkan motivasi belajar adalah sesuatu yang menimbulkan semangat belajar sehingga terjadi perubahan perilaku. Tempat penelitian di SMP Era Pembangunan 3 Jakarta yang beralamat di Jalan Gaga Alastua No. 122 Semanan Kalideres Jakarta Barat.

Berdasarkan pembatasan masalah, permasalahan penelitian ini yaitu: apakah terdapat pengaruh positif antara iklim kelas terhadap motivasi belajar peserta didik kelas VIII pada mata pelajaran pendidikan kewarganegaraan?

Adapun manfaat penelitian ini adalah:

1. Manfaat Teoritis

a. Bagi Penulis

Dari penelitian ini penulis berharap akan mampu memberikan bahan kajian dalam menambah pengetahuan mengenai pendidikan dan proses belajar, khususnya pengaruh iklim kelas terhadap motivasi belajar kepada peserta didik dalam pembelajaran pendidikan kewarganegaraan.

b. Bagi Pembaca

Diharapkannya dari penelitian ini dapat memberikan informasi bagi pembaca untuk mengetahui cara menumbuhkan motivasi belajar kepada peserta didik.

c. Bagi Universitas Pamulang

Hasil penelitian ini diharapkan dapat dijadikan sebagai tambahan daftar pustaka, wawasan, bahan referensi serta 
bahan pertimbangan pemikiran bagi yang memerlukan khususnya yang ingin mengadakan penelitian.Penelitian ini juga diharapkan dapat turut serta memberikan sumbangan pemikiran terutama dalam pengembangan ilmu pendidikan khususnya pendidikan kewarganegaraan.

2. Manfaat Praktis

Bagi Sekolah

Dari hasil penelitian ini dapat memberikan informasi sebagai bahan pertimbangan dalam pengambilan keputusan untuk meningkatkan motivasi belajar dengan pengelolaan iklim kelas dalam proses pembelajaran guna mewujudkan tujuan pembelajaran khususnya pada pelajaran pendidikan kewarganegaraan.

\section{METODOLOGI PENELITIAN}

Penelitian ini bertujuan untuk menguji secara empiris pengaruh iklim kelas terhadap motivasi belajar. Penelitian ini dilaksanakan di SMP Era Pembangunan 3 Jakarta yang beralamat di Jalan Gaga Alastua No. 122 Semanan Kalideres Jakarta Barat.

Metode penelitian yang digunakan dalam penelitian ini dengan metode deskripsi kuantitatif dengan pendekatan studi korelasi. Didalam penelitian ini diduga terdapat adanya hubungan timbal balik antara variabel yang disebut korelasi (Arikunto, 2014). Populasi target pada penelitian ini adalah peserta didik di SMP Era pembangunan 3 Jakarta. Dari tiga kelas di SMP Era Pembangunan 3 Jakarta tersebut dilakukan random (undian) melalui kocokan selanjutnya dijadikan populasi terjangkau. Populasi terjangkau pada penelitian ini adalah kelas VIII SMP Era Pembangunan 3 Jakarta, maka penelitian ini dilakukan pada peserta didik kelas VIII.

Teknik pengambilan sampel yang digunakan dalam penelitian ini adalah random sampling, menentukan besarnya sampel yang menggunakan rumus solvin. Jadi sampel dalam penelitian ini adalah sebanyak 66 peserta didik. Teknik yang digunakan dalam penelitian ini adalah random sampling sederhana yang dari jumlah populasi ditentukan sampel sebagai objek penelitia. Dari tabel Proposional Random Sampling dapat disimpulkan bahwa di kelas VIII A peneliti mengambil sampel dari 44 peserta didik diambil sebanyak 15 peserta didik, di kelas VIII B sebanyak 45 peserta didik diambil 15 peserta didik, di kelas VIII C sebanyak 39 peserta didik diambil 13 peserta didik, di kelas VIII D sebanyak 34 peserta didik diambil 12 peserta didik, di kelas VIII E sebanyak 32 peserta didik diambil 11 peserta didik.

Pengumpulan data pada penelitian ini dilakukan dengan menggunakan instrumen berupa kuesioner atau angket. Angket diberikan kepada peserta didik untuk diisi dan dijadikan sampel dalam penelitian guna menjaring data tentang iklim kelas (X) dan motivasi belajar (Y).

\section{HASIL PENELITIAN}

Data iklim kelas (variabel X) diperoleh melalui pengisian instrumen berupa skala likert sebanyak 30 item yang diisi peserta didik sebagai responden.

Berdasarkan Diagram Distribusi Frekuensi Variabel Iklim Kelas menunjukkan 
bahwa data variabel iklim kelas paling banyak pada interval 103,5 dengan frekuensi 24 peserta didik dan paling sedikit data terletak pada interval 124,5dan 131,5 dengan frekuensi 1 peserta didik.

Data motivasi belajar (variable Y) diperoleh melalui pengisian instrumen berupa skala likert sebanyak 30 item yang diisi peserta didik sebagai responden. Dari hasil perhitungan diketahui skor terbesar 136 dan skor terkecil 76, rentangan 60 , mean 105,77, median 113,44, modus 94,5 , varians 175577,59 , simpangan baku 419,01 , penentuan rentangan, banyak kelas, panjang kelas dan ujung kelas pertama variable $\mathrm{Y}$ maka dapat dilihat distribusi frekuensi variabel $Y$.

Berdasarkan Diagram Distribusi Frekuensi Variabel Motivasi Belajar tersebut menunjukkan bahwa data variabel motivasi belajar paling banyak pada interval 93,5 dengan frekuensi 20 peserta didik dan paling sedikit data terletak pada interval 129,5 dengan frekuensi 1 peserta didik.

Perhitungan normalitas dilakukan dengan uji liliefors dengan taraf signifikan $\mathrm{a}=0,10$. Perhitungan normalitas dilakukan untuk melihat apakah sebaran yang akan dianalisis memiliki konstribusi yang normal atau tidak normal.

Tabel Hasil Uji Normalitas

\begin{tabular}{|l|l|l|}
\hline $\mathrm{N}=66$ & $\mathrm{~L}_{\text {hitung }}$ & $\mathrm{L}_{\text {tabel }}$ \\
\hline Iklim Kelas & 1,3727 & 0,1530 \\
\hline $\begin{array}{l}\text { Motivasi } \\
\text { Belajar }\end{array}$ & 1,5220 & 0,1530 \\
\hline
\end{tabular}

Untuk uji sederhana didapatkan persamaan $\mathrm{Y}=19,22+$ 0,788X. Sementara itu, hasil yang diperoleh pengujian linieritas adalah $F_{\text {hitung }}=0,2877$ dengan $F_{\text {tabel }}=2,79$ pada taraf $(a=0,10)$. Maka dapat disimpulkan bahwa bentuk pengaruh antara iklim kelas dengan motivasi belajar peserta didik kelas VIII pada mata pelajaran pendidikan kewarganegaraan di SMP Era Pembangunan 3 Jakarta adalah linier.

Uji keberartian korelasi dengan kriteria sebagai berikut:

1. Terima Ho jika $r$ hitung $\leq \mathrm{t}$ tabel yang berarti tidak ada pengaruh yang positif antara iklim kelas dengan motivasi belajar peserta didik.

2. Tolak Ho jika $r$ hitung $>\mathrm{t}$ tabel yang berarti ada pengaruh yang positif antara iklim kelas dengan motivasi belajar peserta didik.

Dengan hipotesis penelitian:

Jika thitung $>$ taiss maka Ho ditolak; $\mathrm{II}_{1}$ dterima (positif)

Jika thitung $<\mathfrak{l}_{\text {twos }}$ maka Ho diterima; $\mathrm{II}_{1}$ ditolak (negatif).

Berdasarkan hasil perhitungan, maka hasil penelitian nilai indeks korelasi sebesar $r(0,64510272)$ yang dapat di interprestasikan bahwa iklim kelas berpengaruh terhadap motivasi belajar peserta didik kelas VIII pada mata pelajaran pendidikan kewarganegaraan, semakin kondusifnya kelas dalam kegiatan pembelajaran maka semakin tinggi motivasi belajar peserta didik. Sebaliknya jika kelas yang tidak kondusif maka semakin rendah motivasi belajar peserta didik. 
Dari uraian diatas diperoleh hasil perhitungan nilai $t_{\text {tabel }}$ untuk taraf signifikan yaitu $(a=0,10)$ dan diperoleh nilai $t_{\text {tabel }}=1,29492$ oleh karena itu $t_{\text {hitung }}$ $>t_{\text {tabel }}$ atau 6,75307 > 1,29492, maka Ho tolak dan Hi terima, berarti ada pengaruh positif antara iklim kelas terhadap motivasi belajar peserta didik kelas VIII pada mata pelajaran pendidikan kewarganegaraan.

Meskipun penelitian ini telah berhasil menguji hipotesis yang diajukan yaitu terdapat pengaruh yang positif antara iklim kelas terhadap motivasi belajar peserta didik kelas VIII pada mata pelajaran pendidikan kewarganegaraan, namun masih ada keterbatasan dalam penelitian ini seperti keterbatasan waktu untuk mengisi angket oleh setiap responden sangat singkat karena pengisian angket dilakukan hanya satu jam pelajaran (40 menit) sementara jumlah butir soal dari instrument cukup banyak dalam kondisi seperti ini dengan sendirinya pikiran dan perasaan responden tidak terkonsentrasi penuh untuk menjawab pernyataan dalam instrument secara baik.

\section{KESIMPULAN}

Penelitian ini dimaksud untuk mengetahui bagaimana pengaruh iklim kelas terhadap motivasi belajar peserta didik kelas VIII pada mata pelajaran pendidikan kewarganegaraan di SMP Era Pembangunan 3 Jakarta. Dimana berdasarkan pada analisis data yang dapat ditarik kesimpulan sebagai berikut:

1. Bahwa dari perhitungan statistik yang menggunakan rumus korelasi product moment maupun dengan menggunakan uji $t$, ternyata terbukti terdapat pengaruh antara iklim kelas terhadap motivasi belajar peserta didik hal ini berdasarkan perhitungan dalam uji hipotesis yang menghasilkan $r$ hitung $>\mathrm{r}$ table atau 0,645 > 0, 204 artinya faktorfaktor yang terdapat pada variabel $\mathrm{X}$ berpengaruh terhadap variabel $\mathrm{Y}$.

2. Untuk membuktikan adanya pengaruh positif antara variabel $X$ terhadap Y maka dilakukan uji $\mathrm{t}$ dimana Iklim kelas berperan positif dalam meningkatkan motivasi belajar, sesuai dengan hasil pengujian hipotesis yaitu $t_{\text {hitung }}<t_{\text {tabel }}$ atau $0,64510<1,29492$ sehingga dapat disimpulkan bahwa variabel $\mathrm{X}$ dan variabel $\mathrm{Y}$ terdapat pengaruh yang positif.

\section{REFERENSI}

Aripin, Z. 2011. Penelitian Pendidikan. Bandung: PT Remaja Rosdakarya.

Abin, S. M. 2005. Psikologi Kependidikan. Bandung: PT Remaja Rosdakarya.

Arikunto, S. 2014. Hubungan Antara Minat Belajar Peserta Didik Terhadap Hasil Belajar Pendidikan Kewarganegaraan. Skripsi Eti. Universitas Pamulang.

Depdikbud. 2013. Pengaruh Iklim Kelas dan Lingkungan Keluarga Terhadap Motivasi Belajar Siswa Kelas X Jurusan Administrasi Perkantoran Pada Mata Pelajaran Kompetensi Kejuruan Administrasi Perkantoran di SMK PGRI 2 Salatiga. Skripsi Juliyana. Universitas Negeri Semarang. 
Djaali. 2011. Psikologi Pendidikan. Jakarta: Bumi Aksara.

Hamzah. 2011. Perencanaan Pembelajaran. Jakarta: Bumi Aksara.

Karwati, E. 2015. Managemen Kelas. Bandung: Alfabeta.

Komarudin. 2012. Ilmu Kewarganegaraan. Tangerang Selatan: Asmoro Mediatama.

Komarudin. 2013. Strategi Pembelajaran Pkn. Tangerang Selatan: Asmoro Mediatama.

Muhidin, A. 2015. Statistik: Panduan Untuk Analisis Inferensial. Tangerang Selatan: Universitas Pamulang Press.

Purwanto, N. 2010. Psikologi Pendidikan. Bandung: Remaja Rosdakarya.

Ratna, W. D. 2006. Teori-teori Belajar dan Pembelajaran. Bandung: Erlangga

Sanjaya, W. 2006. Strategi Pembelajaran. Jakarta: Kencana.

Syaiful, B. D. (2010). Strategi Belajar Mengajar. Jakarta: PT Rineka Cipta.

Syah, M. 2012. Psikologi Belajar. Jakarta: PT Raja Grafindo Persada.

Ubaedillah. A, \& Rozak, A. 2003. Pendidikan Kewarganegaraan. Jakarta: ICCE UIN Syarif Hidayatullah.

Undang-Undang Republik Indonesia Nomor 20 Tahun 2003 tentang Sistem Pendidikan Nasional. 2004.
Jakarta: PT Gramedia Pustaka Utama.

Wahab, R. 2015. Psikologi Belajar. Jakarta: Raja Grafindo Persada.

Willis, S. 2012. Psikologi Pendidikan. Bandung: CV Alfabeta.

Arianti, P. 2014. Pengaruh Iklim Kelas Terhadap Motivasi Belajar Mahasiswa: Jurnal Administrasi Pendidikan Universitas Pendidikan Indonesia Volume 3, No. 1,3-4.

Brantaningtias, D. 2012. Hubungan Antara Persepsi Terhadap Iklim Kelas Dengan Motivasi Belajar Siswa: Jurnal Empathi Fakultas Psikologi Universitas Ahmad Dahlan Volume 1, No. 1, 63.

Hadinata, P. 2009. Iklim Kelas dan Motivasi Belajar Siswa SMA: Jurnal Psikologi Universitas Gunadarma Volume 3, No. 1, 93-97.

Tarmidi. 2006. Iklim Kelas dan Prestasi Belajar: Jurnal Psikologi Fakultas Kedokteran Universitas Sumatera Utara, 2.

www.beritasatu.com/.../260463pendidikan-indonesia-tertinggalakibat-kualitas-guru Minggu,26,Maret,2017.11:22 www.beritasatu.com/pendidikan/379241mendikbud-kualitas-guru-wajibdiutamakan...Minggu,2 April 2017.12:18 
Jurnal Pendidikan Kewarganegaraan,

Vol. 4, No. 1, Maret 2017
Available online at http://openjournal.unpam.ac.id/index.php/PKn

[ halaman ini sengaja dikosongkan ] 